Karl Aiginger

\title{
Populism: Root Causes, Power Grabbing and Counter Strategy
}

Populism can range from persuasive politics to a dangerous agenda that creates internal and external conflict, negates climate change and rejects human rights. We carve out four root causes of populism. The dominant cause in a period or area determines the socio-economic structure of voters. Populism can have a left-wing or right-wing agenda, and it accelerates with regional problems, inequality, spatial disequilibria and migration. Populist parties often become part of democratically elected governments by forming coalitions with mainstream parties, in which they play the more active part and make further inroads until they dominate. If they finally take the lead, they clinch it by changing the rules, dismantling the division of power between government, parliament and the courts. They invent a foreign enemy or a dangerous force to cement their power. We venture to delineate a counter-strategy that requires four steps.

\section{Definitions of populism and variants}

The broadest definition of populism is that it is an oversimplified interpretation of a society's problems. This strategy has been applied by many successful and also visionary politicians including Roosevelt and Luther King in the US, Churchill or Kreisky in Europe, Che Guevara in Latin America and Mandela in Africa - who were able to popularise their messages to a broad audience. Today, populist communication may to an extent be delegated to media agencies or spin doctors, but it still requires an eloquent transmitter to the electorate.

The common unifying feature of the more dangerous type of populism is that it develops a polarising message: It divides people into two groups and even does this binarily - into the 'us' and the 'them'. The former are the ordinary, virtuous citizens and the latter a corrupt, self-serving elite. One corollary of this is that populists understand the 'true wants' of the people and have the sole ability to serve

(C) The Author(s) 2020. Open Access: This article is distributed under the terms of the Creative Commons Attribution 4.0 International License (https://creativecommons.org/licenses/by/4.0/).

Open Access funding provided by ZBW - Leibniz Information Centre for Economics.

Karl Aiginger, Policy Crossover Center, Vienna-Europe; and Vienna University of Economics and Business, Austria. them; the other is that there exists a natural, positive homogeneity of 'our' people in contrast to sinister foreign forces and cultures that seek to intrude our country, nation and religion (population exchange).

Literature calls it radicalism or nativism when hard ideology is added, whether it is a radical left-wing ideology such as Maoism or a right-wing ideology such as fascism. This can manifest itself in dangerous left- and right-wing populism, as represented by Castro and Chavez on the one extreme and Pinochet, Orbán and Kaczynsky on the other. Both extremes thrive on conflict, populist policy, a dismantling of the division of power, with restrictions on media freedom and democracy at home and a military build-up and closing of borders abroad.

One predecessor of today's populism was the agrarian movement which mobilised small farmers against nobility, large banks and monopolies. Left-wing, reform-oriented populism sometimes included Christian liberation theology, which encouraged protests or revolution against dictators and military rulers who were cooperating with or being financed by the US. This strand was less polarising and more emancipatory, as it encouraged people without power or even voting rights to change their lives and earn fair incomes. The student movement of 1968 encouraged individuals to think 'more dimensionally' about their lives and fight against explicit and implicit oppression. The majority rejected force as a political instrument. There existed, however, elitist concepts for a better understanding of the true wants of a society through academic knowledge, thus disconnecting from the problems of blue-collar labour and trade unions.

While progressive leftist populists are represented at the political front by Bernie Sanders and Jeremy Corbyn, movements like Occupy Wall Street, the Extinction Rebellion and Fridays for Future are at the vanguard of green populism, without a dangerous agenda. The Arab Spring connected the Internet generation with broader parts of the population to fight against traditional rulers hiding money abroad and oppressing people at home.

\section{Four root causes of populism}

For today's populism, we carve out four root causes: economic problems, cultural causes, the speed of change generated by globalisation and digitalisation, and last but not least the failure of policy to manage a transition to higher welfare, globally and locally. 


\section{Economic causes}

Economic causes can be low growth, rising unemployment and inequality. These problems are to an extent fallout from the financial crisis of 2009 that occurred despite political leaders having learned a lot from the Great Depression of the 1930s. ${ }^{1}$ This time, the big economic powers and their central banks did not resort to protectionism or 'my-country-first' strategies. These would have led to a worldwide depression of the economy. Instead, this time fiscal policy was coordinated and expansionist; it stimulated demand, rescued failing banks and refrained from protectionism. Central banks supported fiscal policy by flooding markets with liquidity, employing unusual and innovative instruments, including buying government bonds and even shares in private firms. Nevertheless, it took five years for Europe to reach its pre-crisis output again. Meanwhile, unemployment had climbed to two-digit levels and youth unemployment had skyrocketed to $40 \%$ or $50 \%$ in some countries. The US, which had to a large extent caused the crisis, came out of the recession earlier, inter alia because it pressed payments out of large European banks by threatening to revoke permission to extend operations in the US. It could furthermore increase debt and public deficits more strongly, and was not limited by differences in the credit ratings of states as in Europe.

Thus, the successful demand stabilisation and advantages of international coordination prevented a larger crisis. However, seen in a certain light it also vindicated today's dominant populist proposals, which assert that national strategies are always better and that coordinated European policy contrasts with the interests of ordinary people. However, the attenuated economic dynamic disappointed voters as inequality could not be reduced. In the US, growth rebounded earlier but the stagnation of the wages of blue-collar workers extended into a fourth decade. Firms remained innovative but hurried to exploit innovations abroad since these further ballooned profits. The huge deficit in the US balance of payment has thus been caused by firms greedy to sustain high dividends and serve the top $1 \%$ - not by Chinese distortion of rule, currency manipulations or the stealing of patents by China. This was well understood by economists and international organisations, but the voters accepted the message that innocent American firms were being thrown out of the market by cheap Chinese goods. By the way, the declining prices of consumer goods did more for lowincome earners to increase welfare than rising wages. An electorate ignoring the well-known deficits of the US

1 K. Aiginger: The Great Recession versus the Great Depression: Stylized Facts on Siblings That Were Given Different Foster Parents, in: Economics, Vol. 4, No. 18, 2010. democracy such as campaign financing through lobbies and big money, varying rates of voter registration based on income and race, and Russian interference via social networks led to the victory of a populist president demanding to put "America first" and "make America great again". Ironically, the rust belt voted for Donald Trump, hoping that he would bring industry back home; however, the focus was on traditional, basic goods such as steel and chemical firms powered by fossil energy, which is the wrong specialisation for a country that is a leader in technology and per capita income.

The rising income inequality among individuals, but also increasingly across regions, is a driving force of today's populism. Income and population are increasing in urban centres and modern industrial districts, while in the periphery there is low growth and low investment from international firms, since they need skilled labour and supplier networks. Europe had always complained of a low regional mobility of workers, which increased in the past ten years. This is partly the effect of European enlargement, through which regions near the centre have gained by acquiring dynamic clusters of investment, e.g. in the automotive industry. The populations in the regions left behind have significantly decreased. One-fifth of male workers between the ages of 20 and 30 have left, and the prediction is that the population in this group will reduce by half by $2050 .^{3}$ Affected regions feel forgotten by national policy and threatened by the free movement of workers that constitutes one of the four freedoms of the European single market. The large and increasing EU regional and structural funds were not seen as compensation. This could be because a large part of these funds were diverted by dominant firms or the political elite. Another possible reason is that the declining regions were not able to define projects and cope with the red tape needed for successful fund applications.

\section{Cultural causes}

Cultural causes for populist voting can be connected with changes in value systems that are described in literature as gradual changes in Western society's values, from conservative to liberal. The latter values range from equality of gender and acceptance of different partnerships and lifestyles to ideas about healthy nourishment, mandatory seatbelts in cars and stricter speed limits.

2 K. Aiginger: Political Rebound Effects as Stumbling Blocks for Socio-ecological Transition, in: American Journal of Business, Economics and Management, Vol. 6, No. 1, 2018, pp. 7-15.

3 K. Aiginer, H. Handler: Toward a European Partnership Policy (EPP) with the South and the East, Forstering Dynamics, Fighting Root Causes of Migration, Policy Crossover Center: Vienna-Europe, Working Paper No 3, 2017. 
Opposition to political correctness and gender consciousness has increased gradually and has now found a political outlet. The resurgence of male dominance is fostered if the potential second income earner no longer applies for jobs due to a lack of well-paid jobs or stagnant or declining wages (or inherited wealth). This is the case in Europe, as well as in the United States (e.g. the Tea Party Movement).

The fact that life expectancy has declined in the US, due to unhealthy eating and sugared drinks leading to obesity, and opioids, does not play a role in this discussion, nor that it has decreased more significantly in low-income groups and among people not born in the US. Preventing their immigration was perceived as more important than integrating them and upgrading their lifestyles. The US can no longer boast about its ability to allow everyone to change their life through upward mobility.

\section{The speed of change}

Lifetime jobs have become the exception, and young people seldom pursue the same occupation as their elders. What one does at the start of a career cannot become a job for decades - even if the job is formally the same, its content, activities and tasks to be performed will change. Kids do not work in the same firms and jobs as their parents and are flexible in changing the location of their work. Their personal, religious and political priorities are less homogenous and can be different from those of their parents. This widens choices, increases the fit between abilities and demand and thus leads to lower levels of skill mismatch, but it also involves uncertainty and can result in intermittent periods of joblessness and retraining.

\section{Economic policy has not delivered}

Even mainstream globalisation theory predicted that there would be losers and that these would be the lowskilled workers in the industrialised countries. Theory asserts that they should be compensated for their losses. However, modern theory stresses that this cannot be done completely, and opinion surveys show that people do not wish to depend on welfare payments for long periods, preferring instead to change jobs or occupations. ${ }^{4}$

Thus, globalisation and the resulting speed of change are generally heading in a positive direction but require a game-changing transformation of the education system. Learning by heart has to become less important than

4 P. Collier: The Future of Capitalism, London 2018, Penguin Random House UK. problem-solving, and there is a shift from a one-off phase of education in youth to lifelong learning, retraining and a constant search for new opportunities and improvements. Empowerment substitutes social compensation as a best-policy reaction. The worst approach is ignoring the losers' problems and calling for a return to nonexistent past glory.

Migration is seen as an accelerator or driving force of populism. ${ }^{5}$ If people have fewer opportunities and a stagnant income, they oppose migrants as new competitors who are willing to work at lower wages for longer hours. The opposition remains even if the entrants are not close substitutes for the old jobs and even if inward migration and extending the workforce lead to higher output and an increase in domestic employment. When uncertainty is high, migration is not seen as an opportunity but as the threat of losing position, of declining from middle to lower class. This impression is heightened when regions lose jobs, which are being created in the centres to which migrants flock.

In general, former rust belts and forgotten regions where the populations are declining tend to turn to populist parties, even if mainstream parties or European policies support investment and aid is provided, and even if former citizens finance an increasing part of the community or the family budget by sending money home. Remittances and structural aid make up nearly $6 \%$ of regional GDP und even more in some communities. ${ }^{6}$ However, since these payments cannot be appreciated as the result of own efforts they do not hinder a search for 'strong men' who claim that the past was better, foreigners are the problem and protectionism is the solution. Very few regions offer strategies to bring former expatriates back or invite migrants to make use of the entrepreneurship and broad skills acquired in small businesses in their countries of origin. Social media and echo chambers tend to focus on problems and grievances rather than solutions, and they tend not to report success.

\section{The road to power of populist parties}

The political inroads of populist parties start locally or regionally. People disappointed by economic dynamics often call for some form of independence, whether from the mainstream government or the European Commission. And they may even call for the secession of a

5 K. Umansky, J. Kohlenberger: Hunt or Be Hunted? Immigration as a 'Legitimate' Enemy Strategy in the 2017 Austrian General Election, 2019, mimeo; M. Oberlechner, H. Heinisch, P. Duval (eds.): Nationalismus bildet, Schwalbach, forthcoming, Wochenschauverlag.

6 K. Aiginger, H. Handler, op. cit. 
province, at least if the 'government does not change its course'. There are often two mainstream parties which are short of the absolute majority; instead of one supporting a prime minister of the other, the smaller one invites the populist party to become a member of the government or the larger one, in order to prevent this, invites the populist party itself. In such coalitions, the populist party determines the political agenda and becomes dominant. If new elections show increased support for the populist party, it then changes the rules of voting, so that a minority party can get the majority of seats. Then the populist party may further change the rule of law, abolish the division of power, forbid opposition and foreign papers, and try to dominate social media and gain internet control.

The economic agenda of bringing jobs back and improving dynamics can sometimes work in the short run, if past fiscal prudence has left some space for higher government expenditures for low incomes. However, in the long run, protection and redistribution without active components, innovation and new firms do not work. To distract from the negative economic consequences, a foreign enemy has to be created; this can be the EU, international migration, the big international media or expatriates like George Soros in Hungary. Suddenly, everyone from abroad appears to be against 'us'. 'We' have to stick together, increase political control, bolster the police force and try to protect our borders from foreign goods and people from other cultures.

\section{A strategy for overcoming populism in four steps}

To stop support for populists and put an end to their power is no easy task. The root problems, which had empowered the populists, have not vanished, and the incapacity of former mainstream parties to solve problems has not been forgotten. Support for populists eventually fades if the economic situation worsens - as the electoral results in main cities in Turkey and Hungary show. However, if there is no candidate presenting an alternative or opposition is divided, the return to liberal democracy is difficult, given the new majority rules and suppression of the media. A four-stage procedure is needed.

The first step is to correct the wrong framing on which today's populism is based. It is the pessimistic interpretation that life has become bad, the economy is approaching a collapse, and moral and social relations are worse than in some golden era. In fact, in most countries and regions, living conditions were not dismal at the time the populists came to power. Incomes were higher than those of the previous generation, there was a greater ability to choose education, training and location. The best proof that an overly pessimistic story is incorrect is perhaps rising life expectancy: it increases by three years for each decade after we were born, and it is largely a healthy life expectancy that includes the ability to work, travel and seek a partner up to an age that had previously been unimaginable. In rebalancing the framework it has to be acknowledged, that not everything is positive for everyone and the potential for improvement is great. Inequality can be decreased, employment made fairer with less burnout, and leisure choices can increase. It must be made clear that these improvements will never happen through protectionism, and that past jobs and family structures will not return. Furthermore, it needs to be stressed that heterogeneity is not negative and animosity towards outsiders or foreigners does not solve problems. Redrawing the picture without whitewashing must be the starting point of a new policy.

The second step is to develop a vision outlining where the country or region wants to be in the medium-term future, for example by 2030 . This includes which jobs can be created, which specialisations by industry are feasible and advantageous, and which abilities and education levels for the young can be attained. The vision should specify which public services are to be provided and how living conditions can be improved. Performance should be judged based on sustainable development goals. ${ }^{7}$ The vision should be ambitious but within reach, shared by citizens and developed jointly with experts and political parties.

The third step is to define game-changing instruments and find partners in the process of change. ${ }^{8}$ Changing tax systems are all-important as they can make environmental exploitation costly while supporting a circular economy and innovation. Lifelong learning and retraining should be further promoted. The strategy should be discussed and fine-tuned in a dialogue with citizens, NGOs, reform-minded trade unions and representatives of new firms. Moreover, the skills of migrants should be utilised and their children integrated. The increase in spatial divergence has to be stopped. The flocking to urban centres should be curtailed through teleworking and teleconferencing. Buying ever bigger cars fuelled by

7 A. Köppl, S. Schleicher, M. Schratzenstaller: Policy Brief: Fragen und Fakten zur Bepreisung von Treibhausgasemissionen, Wien 2019, WIFO.

8 K. Aiginger: European Partnership Policy: Fostering Dynamics and Fighting the Root Causes of Migration, Policy Crossover Center: Vienna-Europe, Policy Brief No. 3, 2017; K. Aiginger: Education: Key to Welfare and External European Partnerships, Policy Crossover Center: Vienna-Europe, Policy Brief No. 2, 2018. 
gasoline or diesel should be discouraged through better public transport, incentives for electric cars and car sharing, and the renting of unused houses should replace urban sprawl.

Finally, a new strategy requires a narrative that emotionalises and unites Europe. Europe's old peace narrative no longer moves its citizens, though each and every day we see that peace is not a guarantee. Since Europe is a small geographical region and Europe's share of the world population is proportional in size, this must be a narrative based on quality, innovation and partnership.

A probable new narrative could be that Europe is trying to make globalisation responsible, taking the lead in fighting climate change and offering a larger variety. It can further aspire to the lowest inequality for its citizens, encouraging the extension of this European way of life.

\section{Change is around the corner}

Fighting populism is a necessity. Populism reduces life opportunities, promising a return to non-existent past glory. It leads to lower income and higher expenditures for people unable to find jobs and a self-determined life. It increases the probability of conflict with neighbours. Under populism, government expenditures for policy, border control, environmental degradation and health problems must increase significantly, and this in turn leads to higher taxes and debt. It has multiple roots which must be addressed, but there exist numerous better solutions for these problems if they are discussed with citizens.

While support for populism seems to have peaked, an active policy is still needed to ensure its continued decline. Fortunately, the new president of the European Commission and her team are addressing these problems, with the support of new leaders at the IMF, the UN and the ECB. Economists seem to have partly descended from their ivory tower to include societal and environmental problems in their agenda, with GDP substituted by Sustainable Development Goals. New interdisciplinary think tanks are on the rise, and these are connected to international networks stimulating discussion. Young people are more interested than ever in the future of the planet and infecting their parents and teachers with their concerns. New political parties are being created on a basis other than that of the old socialist-vs-conservative divide, and governments are becoming greener, more liberal and more attentive to future opportunities opportunities and partnerships with neighbours in the East and in the South. 